\title{
Writing a Novella to Introduce Tourism Objects in Palembang
}

\author{
Nurul Aryanti', Murwani Ujihanti ${ }^{2}$, Welly Ardiansyah ${ }^{3}$, Vani Annas Tasya ${ }^{4}$, Vasa Annisa Indina ${ }^{5}$ \\ 1,2,3,4,5English Department, Politeknik Negeri Sriwijaya, Palembang, Indonesia
}

\begin{tabular}{l}
\hline Article Info \\
\hline Article history: \\
Received Oct 12, 2021 \\
Revised Dec 10, 2021 \\
Accepted Dec 25, 2021 \\
\hline
\end{tabular}

\section{Keywords:}

Writing

Creative Writing

Novella

\begin{abstract}
This research was aimed at knowing how to write a novella entitled "Allied" to promote several tourism destinations in Palembang. In research, the researchers used research and development (R\&D) method. The researchers conducted two steps of R\&D method: (1) preliminary study, which involved literature study, field study, and product drafting, and (2) model development, which were limited testing and wider testing. The researchers implemented these steps by developing the product. The data were collected from observation and interview in preliminary study step. In model development, the draft of novella regarding the language, structure of sentence, and the content of the story was revised by several experts. The novella was written in English by using Final Draft as the software of writing a story. The story was wrapped in action genre by bringing some mystery in tourism destinations in Palembang that would entertain and educate the readers at the same time. Additionally, in writing a novella entitled "Allied" there were three steps that were conducted with R\&D method by Sukmadinata (2015) which the steps were linked to the sixth steps of writing a story by Grenville (2001): Getting Ideas, Choosing, Outlining, Drafting, Revising, and Editing.
\end{abstract}

This is an open access article under the CC BY-SA license.

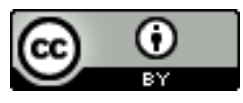

\section{Corresponding Author:}

Nurul Aryanti

English Department,

Politeknik Negeri Sriwijaya,

Jalan Srijaya Negara, Bukit Besar, Palembang, Indonesia.

Email: aryantinuru1479@gmail.com

\section{INTRODUCTION}

Most of people would probably think that writing is a complicated and boring activity to do. One of the reason is because the stigma of writing is identical with academical writing like essays, journals, articles and dissertations. However, writing can be more than putting the information through paper. On the other hand, writing can be interesting and fun activity to do especially when it comes to use creativity. The activity of writing in creative way is known as creative writing.

Creative writing offers a new way for writers to play with language, imagination, and innovation. Creative writing uses senses and emotions in order to create a strong visual in the reader's mind whereas other forms of writing typically only leave the reader with facts and information instead of emotional intrigue [1]. Therefore, it can let the writer to create a pleasure works that seems fun to be read. This work includes poetry, scripts, screenplays, creative non-fiction, and fiction story.

Fiction story commonly used for entertaining, and it can be a media of learning for the reader. Besides, it can be used as a promotion way, especially in tourism field. Regarding to this issue, a research shows that tourists visit places that were accurately portrayed in books, and those that were used as an inspiration for fantastical settings in literature [12]. In addition, there are some types of fiction story, such as short stories and novels that can be used for promoting tourism destination. 
One of the success fiction works in promoting tourism destination is a best seller novel, namely Laskar Pelangi. This novel is written by Andrea Hirata and was published in 2005. The novel brings some tourism destinations in Bangka Belitung as setting in the story. Turns out, Laskar Pelangi has successfully increased a number of visitors in Belitung Island since the novel could leave a deep impression for the readers. Based on the data [10], the visitors of Belitung island increased after the novel released.

Realizing how success the novel was, inspires the researchers as the student and lecturer of tourism and hospitality industry to contribute in the same way in order to promote tourism destination especially in Palembang. This city is one of the metropolitan cities in Indonesia that has potency to be developed especially in tourism. There are several iconic tourism objects with great historical values in the city. In addition, it has many cultures which are attractive such as traditional food and language. Knowing the potency, the writer choose a novella as the media to promote the tourism destination. It is considered a novella, not as long as novel and not too short like a short story.

The novella is written in English and wrapped in action genre by bringing some mystery with riddle in some tourism destinations in Palembang as the setting place in the story. It is as a hope to attract the reader curiosity and leave deep impression about how the situation in Palembang and finally they probably would be interested in visiting Palembang as a tourist. Moreover, the novella will be published on Wattpad as the world's most-loved social storytelling platform, thus it can be read by many readers from all over the world.

Reading a novella can fly the reader's minds to the places in the story. That is one of the best appeals novella presents for the readers. It leads the researchers to believe that writing a novella can be a way to contribute promoting tourism destination in Palembang.

\section{RESEARCH METHOD}

The researcher used research and development (R \& D) method as the method to do this research. There are three stages of the method [8]. The stages were briefly described in sequence as follows:

1. Preliminary study. The first stage was preliminary study. This stage consisted of three steps, there were; (1) literature study, (2) field study, and (3) product drafting.

2. Model Development The next stage was model development which is consisted of two steps. The first was a limited testing and the second step was a wider testing to develop the product.

3. Final Product Testing and Dissemination. The last stage is final testing. This stage aims to test the products that have been developed from the previous stage to produce the final product.

The three stages were formulated into the chart of research procedure as following;

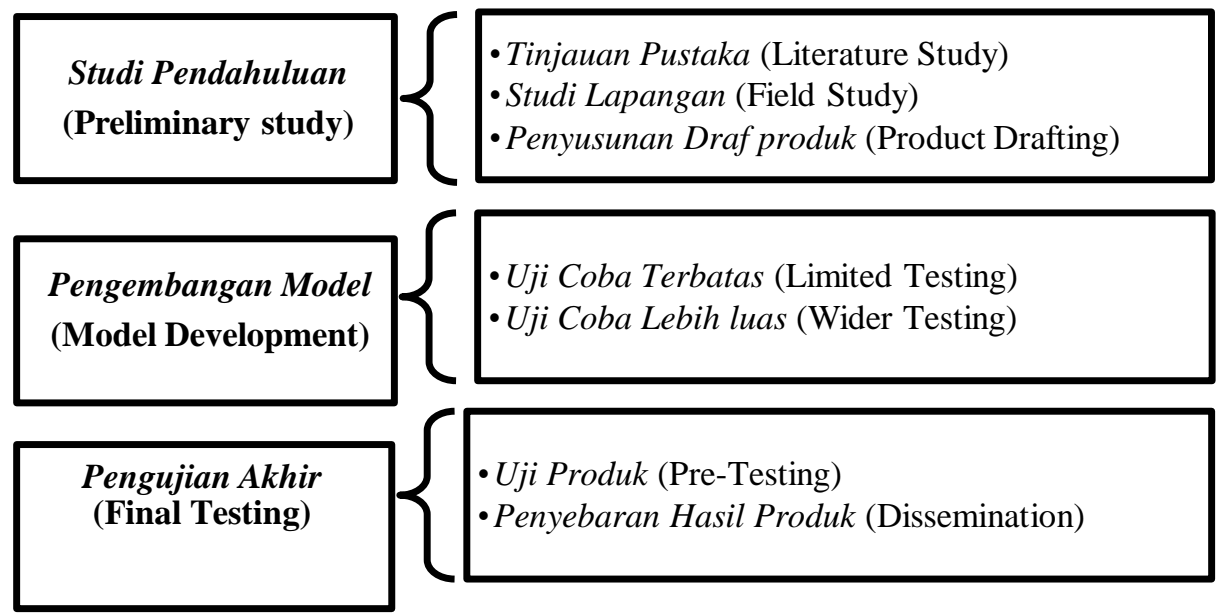

Chart 2.1.

The Stage of R\&D Modified

Sources: Sukmadinata (2015)

Furthermore, the researchers found that the stages [8] linked to the six steps of writing a story [5] as illustrated in the chart below:

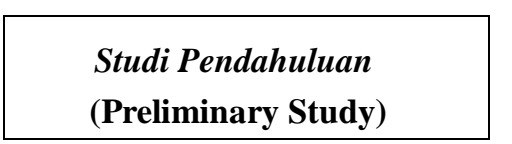
Steps of Writing a Story




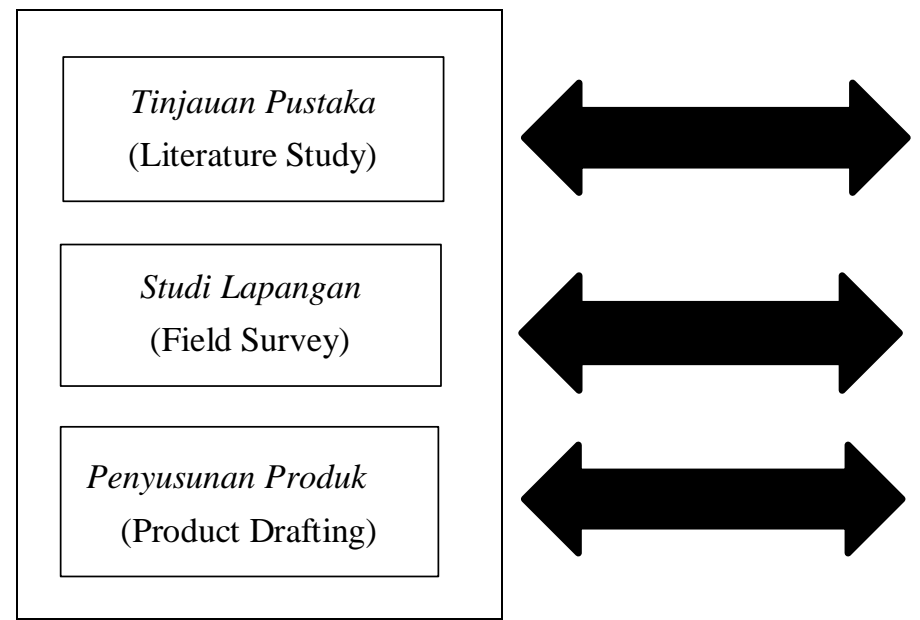

(Sukmadinata, 2015)

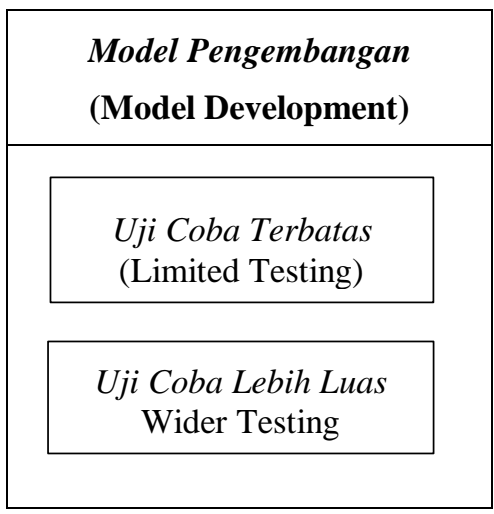

(Sukmadinata, 2015)

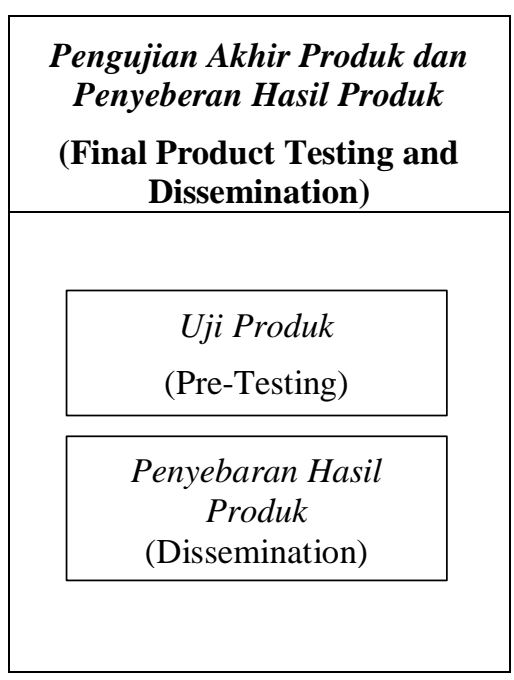

(Sukmadinata, 2015)

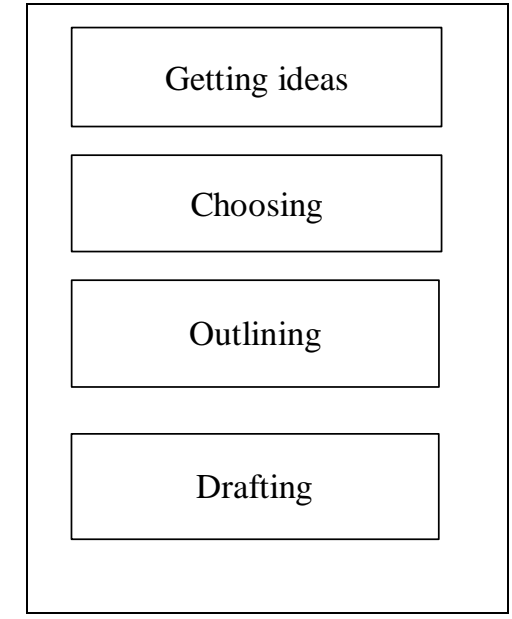

(Grenville, 2001)

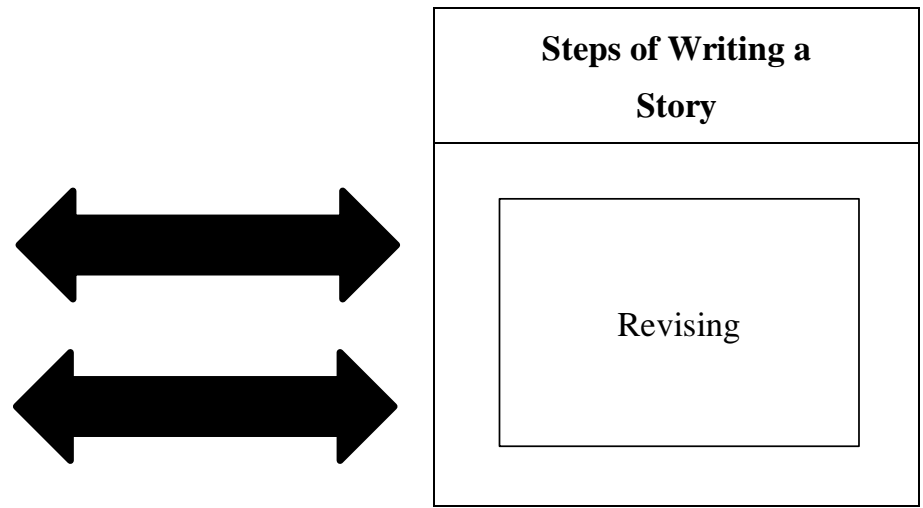

(Grenville, 2001)

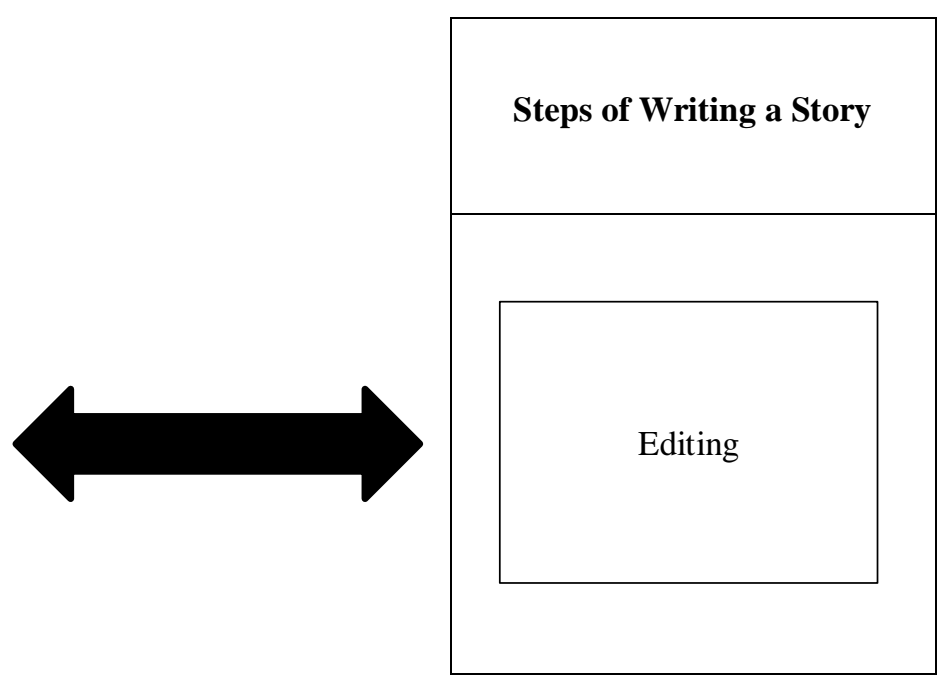

(Grenville, 2001)

Chart 2.2. Stages of Simplified R\&D by Sukmadinata (2015) and Steps of Writing a Story by Grenville (2001)

\section{RESULTS AND DISCUSSION}

The three stages used, consist of Preliminary Study, Model Development, and Final Product and Dissemination [8]. Those three stages were linked to the steps of writing a story [5]; getting ideas, choosing, outlining, drafting, revising, and editing.

International Journal of Research in Vocational Studies, Vol. 1, No. 3, December 2021: 78 - 89 
Preliminary study is the first step which is known as the preparation process in research and development modifications steps. The writer did three steps in the process; they were literature study and field survey (getting ideas, choosing), then arranging the model draft (outlining, drafting). In getting ideas for the story of the novella, the writer builds an idea that will be written in the novella. It started by determining the theme and the genre. The writer decided to write the novella with action genre by bringing mystery and riddle in some tourism destinations in Palembang. Furthermore, the writer read some books, journals, and novel that related to the product. The writer then did the second step of writing a story that was choosing. The ideas were chosen about several names including the characterizations for several main characters and some tourism destinations as setting in the story.

The next step was model draft, it was to outline [5] ideas in steps of writing a story that was implemented in field survey [8]. In this step, the writer did a survey to some bookstores, explores some tourism destinations, interviewed some respondents in order to collect some data for the content story of the novella. Finally, the writer made the outline of the novella regarding the plot or time sequences including the point of view of the story. The outline of the novella can be seen in the table below:

\begin{tabular}{|c|c|}
\hline Title & Allied \\
\hline Genre/Theme & Action \\
\hline Languages & English, Dutch, and Indonesian \\
\hline Point of View & Third Person Point of View \\
\hline Settings & $\begin{array}{l}\text { 1. Netherlands: The Hague } \\
\text { - } \text { The Headquarters of Dutch Military Intelligence and } \\
\text { Security Service (MIVD) } \\
\text { 2. Indonesia: Palembang } \\
\text { - Benteng Kuto Besak } \\
\text { - Ampera Bridge } \\
\text { - MONPERA } \\
\text { - Kemaro Island } \\
\text { - Pasar 26 Ilir }\end{array}$ \\
\hline Characters & $\begin{array}{l}\text { 1. Daan Bergsma (Dutch CIA Agent) } \\
\text { 2. Hikari Sakishima (Japanese CIA Agent) } \\
\text { 3. Atryana (Indonesian Tour Guide) } \\
\text { 4. Zuko (Japanese Agent) } \\
\text { 5. Sara (Japanese Agent) } \\
\text { 6. Dutch Lieutenant } \\
\text { 7. Japanese Commander } \\
\text { 8. Uncle Legi (Chinese) } \\
\text { 9. Sabby (Uncle Legi's Son) } \\
\text { 10. Satur (Indonesian Local People) }\end{array}$ \\
\hline Plot (Time Sequences) & Part of Chapters \\
\hline Beginning & $\begin{array}{l}\text { Chapter One } \\
\text { Chapter Two } \\
\text { Chapter Three } \\
\text { Chapter Four }\end{array}$ \\
\hline
\end{tabular}




\begin{tabular}{|c|c|}
\hline & $\begin{array}{l}\text { Chapter Five } \\
\text { Chapter Six }\end{array}$ \\
\hline Middle & $\begin{array}{l}\text { Chapter Seven } \\
\text { Chapter Eight } \\
\text { Chapter Nine } \\
\text { Chapter Ten } \\
\text { Chapter Eleven }\end{array}$ \\
\hline End & $\begin{array}{l}\text { Chapter Twelve } \\
\text { Chapter Thirteen } \\
\text { Chapter Fourteen } \\
\text { Chapter Fifteen } \\
\text { Epilogue }\end{array}$ \\
\hline
\end{tabular}

Table 3.1. Outline of the Novella

In drafting the story, the story is written in English and wrapped with action genre. In designing the novella's covers, the writer asked the illustrator, Mr. Muhammad Lutfi Darussalam from Darussalam Art which used three digital applications such as Photoshop, Adobe Illustrator, and Canva.

The next stage was model development [8] which was carried out technically [5]. This section presents process of reviewing and testing the first draft of novella in order to make the product developed through limited and wider testing. These stages were done by asking experts's comments and suggestions, then revising the draft of the product.

The writer gave the first draft of the novella to 1 expert for limited testing to revise the draft in terms language and content of the story. Meanwhile, in wider testing, the writer gave the novella draft to the 3 experts who have English background and as a bibliophilia or someone who loves to read and to collect English novels to revise and validate the story of the novella.

The last stage of R\&D method is final product [8]. The writer did the sixth or the last step of writing a story which was editing [5]. After getting some revision, suggestion, and advice from the novella draft, the writer did some editing and cutting based on the feedback that she got from revising steps. In writing a final project for under graduated student, the research and development can be stopped until the final draft without product testing [8]. Therefore, the writer stopped the work until wider testing and considered the revision of wider testing as the final product.

\subsection{Discussion}

Based on the findings, the writer will be discussed about the steps of writing a Novella entitled "Allied". Before the writer starts writing a manuscript of the novella, the writer did few steps. Based on the results between literature review and interview, it can be concluded that the steps of writing a novella have the same steps. The steps were also linked to the Research and Development (R\&D) method [8]. Therefore, the writer applied the steps in writing a novella [5]. The steps are: Getting ideas, Choosing ideas, Outlining, Drafting, Revising, and Editing.

\subsubsection{Preliminary Study}

The first stage of Research and Development was preliminary study [8]. This stage was consisted of three stages which were Literature Study, Field Survey, and Product Testing and Dissemination. These stages were linked to four stages of writing a story [5] such as Getting Ideas, Choosing, Outlining, and Drafting.

\subsubsection{Getting Ideas}

In this step, the writer linked a first step of R\&D stages [8] that was Preliminary Study in Literature Study field. In getting ideas for the story of the novella, the writer builds an idea that will be written in the novella. It started by determining the theme and the genre. The writer decided to write the novella with action genre by bringing mystery and riddle in some tourism destinations in Palembang. This genre was considered

International Journal of Research in Vocational Studies, Vol. 1, No. 3, December 2021: 78 - 89 
as one of the cool genres for a story where the average story usually has a romance genre. And above all, it is also expected to leave a deep impression and fun about how the situation in Palembang.

Furthermore, the writer read some books that related to information of writing a fiction story. First, the writer read a book written by an American author entitled Journeys: Common Core Writing Handbook [3]. From the book, the writer got information about the purpose in writing a story. Second, the writer read a book that was written by an Australia author, entitled Writing from Start to Finish: A Six-Step Guide [5]. From the book, the writer got information about the steps and tips for authors in writing a story.

Next, the writer read some journals that related to Novella. At first, the writer read a journal entitled The Origin and Development of English Novel: A Descriptive Literature Review [2]. In this journal, the writer got information about the origin, the meaning of Novella, and the difference between Novel and Novella. Moreover, the writer read another journal entitled Novella [9]. By reading this journal, the writer got information about the length and the word count of the novella itself.

Lastly, besides books and journals, the writer also read some English novels with action and mystery genre since the writer created a novella with these type genres to get information related to the content of the story. The writer read an English novel written by a famous British writer, Peter James (2009) entitled Dead Tomorrow. Then the writer read another English novel written by Marie Lu (2011) entitled Legend: Los Angeles 2130. By reading those novels, the writer found out some information related the style and way of authorship, elements of the novella layout which are consist of cover, prologue, author section, blurb, and epilogue.

\subsubsection{Choosing Ideas}

In this step, still at the same stage Preliminary Study which was linked to R\&D method [8]. After getting ideas about the genre of the novella, the writer continued to determine some ideas for the content in the story of novella. Firstly, the writer determined names including the characterization for several main characters in a story, namely Daan Bergsma, Hikari Sakishima, and Atryana. Secondly, the writer chose some tourism destinations as setting in the story. In this novella, the setting took places in Benteng Kuto Besak, Ampera Bridge, Monumen Perjuangan Rakyat, Kemaro Island and Pasar 26 Ilir. Afterwards, the writer determined the plots how the story would be started and ended.

\subsubsection{Outlining}

In this step, the writer linked the second step of Preliminary Study in R\&D method that was Field Survey [8]. In this stage, the writer did a survey to some bookstores to find out the novella. The writer explored Gramedia World bookstore and Books and Beyond bookstore. From the survey, the writer found there are no novellas and even the novella has never provided in there. Thus, the writer decided to read novella from online application that are Wattpad, JotterPad, and Goodreads websites and got information about the content of the story in the novella such as setting places, font, size and cover.

Furthermore, the writer got to know more information about the style and way of authorship from a mystery novel, Dead Tomorrow written by Peter James (2009). Next, the writer explored some information for the content of the novella which is related to some tourism destinations, that are Benteng Kuto Besak, Ampera Bridge, Monumen Perjuangan Rakyat (Monpera), and Kemaro Island. Due to the pandemic situation which made some of the tourism destinations closed, the writer could not do a direct survey and moreover, Monpera was under repaired and renovation. Thus, the writer only did observation through internet and asked a colleague who has ever visited the Monpera to tell the real situation in there so the writer could imagine and describe it in the story of the novella.

Additionally, the writer interviewed several respondents for information that was needed in the content of the story. First the writer interviewed a respondent who had experiences in the field of writing fiction, Ms. Farisyah Safitri as an author from Dunia Sastra Community. From the interview, the writer got some information. First is she explained several stages of writing a novella namely getting ideas and the genre, building character and characterizations, building a plot from the conflict, the climax, and the resolution, arranging an outline from prologue until epilogue, making targets, and starting to write. Next is she said in writing a novella, the format can be various since there is no limitation and depends on how the author wants to design it. Thus, authors have the right and are free to what they want to include in their novellas.

Secondly, the writer interviewed Mr. Daniël de Boer as a Dutch master degree student regarding a Dutch language and information of the CIA in Netherlands. From him, the writer could know how to write few sentences of greetings in Dutch for example: Hoe gaat met je? Dank u, Dank je well, and so on. Moreover, the name of CIA in Netherlands is called as Military Intelligence and Security Service (MIVD) which focuses on international threats, specifically military and government-sponsored threats such as espionage. 
Lastly, the writer interviewed Mr. Christopher Noel Torres as an American soldier from $25^{\text {th }}$ Infantry Division of United States Army. From him, the writer gained some general information about military things such as the terms used in military, ranks, and types of guns. Based on those observations and interviews, the writer was able to add the information as the content on the story of the novella. 1. Plot

After collecting several data that were needed for the content of the story through interview and observation, finally the writer made the outline of the plot including the point of view in the story. "At its core, plot structure has three sequences of events: beginning, middle, and end" [6]. The plot can be seen with the table below:

\begin{tabular}{|l|l|}
\hline Sequence of Events & \multicolumn{1}{|c|}{ Story } \\
\hline \multirow{3}{*}{ Beginning } & $\begin{array}{l}\text { In the story of novella, it was started by the mysterious } \\
\text { criminal group sent a threatening letter about bombing an } \\
\text { Ampera Bridge in Palembang with Dutch bomb which } \\
\text { involved two countries indirectly that were Netherlands } \\
\text { and Japan. Daan Bergsma, a Dutch MIVD agent and } \\
\text { Hikari Sakishima, a Japanese Naicho agent worked } \\
\text { together in order to complete the mission. }\end{array}$ \\
\hline Middle & $\begin{array}{l}\text { In the story of novella, the middle part of the story was } \\
\text { about when Bergsma, a Dutch MIVD agent started } \\
\text { realizing the exact location of Dutch bomb in one of } \\
\text { tourism destinations in Palembang which was Monumen }\end{array}$ \\
$\begin{array}{l}\text { Perjuangan Rakyat (Monpera). He wanted to carry out his } \\
\text { plan to retrieve the bomb, yet his partner Hikari said to } \\
\text { postpone the plan and attended the Chinese New Year } \\
\text { Lunar with Ana, mysterious local tour guide. Turns out, } \\
\text { on that night the two CIA agents found out there was } \\
\text { something suspicious about Ana and the Dutch bomb has } \\
\text { gone. }\end{array}$ \\
$\begin{array}{l}\text { In the story of novella, the end of the story was started by } \\
\text { two CIA agents have completed the mission that was } \\
\text { finding out the dangerous mysterious group and retrieved } \\
\text { the Dutch bomb in Kemaro Island. Ana, the local tour } \\
\text { guide was also found out that all this time she had a key to } \\
\text { the Dutch bomb from her rose gold pendant. }\end{array}$ \\
\hline
\end{tabular}

\section{Point of View}

Table 3.2. Plot of the Novella

In the novella, the writer used point of view from third person. There are three types of point of views, namely first-person point of view, second person point of view, and third person point of view [7]. The author is likened another person who tells the story without being told as a character. In this point of view, the author uses the pronouns "he," "she," and "they," to refer to all the characters.

\subsubsection{Drafting}

In this step, the writer linked the last stage of Preliminary Study of R\&D method that was Product Drafting [8] and this in line with the fourth steps of writing a story that was drafting [5]. The draft of the novella followed the information that had been collected from the interview, observation, and writer's imagination. Here is the process of drafting the product that has been done by the writer:

1. Start Writing the Story of Novella

The writer made a draft of the novella by writing the manuscript of the story using Final Draft as the software within three weeks, starting from June $15^{\text {th }}, 2021$ and ended in July, $3^{\text {rd }} 2021$. Finally, the manuscript of the novella has about 24.300 words or it is 67 pages in A4 sizes. This means the script of novella has suitable with the Word Counts of Fiction Works. This is supported by the Science Fiction and Fantasy Writers of America (SFWA) on New World Encyclopedia that limits novella to 60 or 130 pages or in count word is between 17,500 to 40,000 words. In addition, the writer also made the opening section, novella's identity, table of content, the content of fifteen chapters, epilogue, and author's profile section.

2. Finding an Illustrator

International Journal of Research in Vocational Studies, Vol. 1, No. 3, December 2021: 78 - 89 
After finishing the script and the contents of the novella, the writer then asked an illustrator from Darussalam Art in order to design the cover of the novella including the front and back cover, the mock up design, and the cover printing.

\subsubsection{Model Development}

In this stage, the writer conducted model development after the draft of the novella has been written. There were 2 stages in model development which were limited testing and wider testing. In model development, the writer did the fifth steps of writing a story which was revising [5]. This stage was done for developing the product to get the best result.

\subsubsection{Revising}

This stage consisted of limited testing and wider testing. In this stage, the writer gave the first draft of the novella to 1 expert for limited testing to revise the draft in terms language and content of the story. Meanwhile, in wider testing, the writer gave the novella draft to the 3 experts who have English background and as a Bibliophilia or someone who loves to read and to collect English novels to revise and validate the story of the novella.

\subsubsection{Revising of Limited Testing}

In limited testing, the writer gave the novella draft to the expert who had experience in the field of writing fiction. She was an American author, Ms. Marissa Pileggi as an author who wrote some novels that are Other Space, For You, Anon, all that Remains, Always Marinette, and published three short stories in different Anthologies. Since the expert was a native author, she checked the language including structure of sentence along the content of the story at the same time.

Ms. Marissa Pileggi said that she really enjoyed the story. She also pressed that the writer had done a wonderful job in writing the story with the action genre. Last but not least she gave the writer an advice since the novella was the writer's first of piece work and should be proud of all her hard work.

\subsection{Revising of Wider Testing}

After getting a first revision from an American author as the expert in limited testing, the writer then did wider testing by giving the novella draft to be read by some people who have English background and as Bibliophilia or someone who loves to read and to collect English novels. First, the writer gave the novella draft to be read by Dr. Nurul Aryanti, M.Pd as an English lecturer in State Polytechnic of Sriwijaya who likes to read and to collect English novels. She said overall the novella is good enough. She suggested the writer to describe more about the identity of Dutch and Japanese agent characters on the story.

Additionally, the writer was also suggested to add the novella's identity. It is in line with the statement that novella identity is one of the layout elements needed in the novella [11]. The identity of the novella is on the page after the front cover containing the title, author's name, supervisor's names, editor's names, and where the novella is printed. Through the suggestions, the writer revised it as shown in this figure:

Next, the novella draft was given to Mr. Atif Farrukh, a Pakistani Chief Technical Officer in Transcendence Tech who likes to read and to collect English novels. In the chapter one, he gave a suggestion about a diction word between a Netherlands bomb and Dutch bomb. He said a diction word of Dutch bomb is more suitable for the name how the bomb is called.

Moreover, Mr. Atif Farrukh also added that the writer has already enough described the situation of the story in bringing the characters of the story lively especially for Atryana as the mysterious tour guide local girl character. He never guessed it till the Chinese New Year event that Atryana might be somehow involved in the mysterious gang. Mr. Atif Farrukh admitted that the author succeeded in creating a sense of mystery in the story.

Lastly, the novella draft was also given to Mr. William John Warren, an American Heavy Equipment Operator in Montana Concrete and Fuel, Inc who likes to read and to collect English novels. Mr. William John Warren said that he was excited to finally complete the cursory review of the novella. Overall, he liked how the writer used the way authorship with creative writing. He enjoyed the mystery and drama scattered throughout. It had him guessing and tied to the edge of his seat. Additionally, he said the writer performed the assignment perfectly especially for the dynamic and unique writing style.

Then he was impressed how the writer used punctuation on quoting conversations. He also added that the story has successfully made him felt curious with the real situation in Palembang especially for the taste of Palembang specialties food that was highlighted on the story. He refused to be too critical of the writer's sentence structure at times because the point and flow of her story left him. The writer can over plain minor details at times but, on the other hand, this was what made the story so rich at times. Lastly, Mr. 
William John Warren added that he was proud of the writer for this huge story as an accomplishment the writer should take pride in.

\subsubsection{Product Drafting}

This is the last stage to develop the product that had been conducted in limited testing and wider testing. This stage consisted of final product testing and dissemination [8]. It was also linked to the last stage of writing a story which was editing [5]. In writing a final project for under graduated student, the research and development can be stopped until the final draft without product testing [8]. Therefore, the writer stopped the work until wider testing and considered the revision of wider testing as the final product. In this stage, after getting some revision, suggestion, and advice from the novella draft, the writer did some editing and cutting based on the feedback that she got from revising steps. Finally, the novella draft can be printed out to a book as the Final Product. Before the writer printed out the novella as a book, here is the mock up design to see how the novella would look like if it is already printed as book.

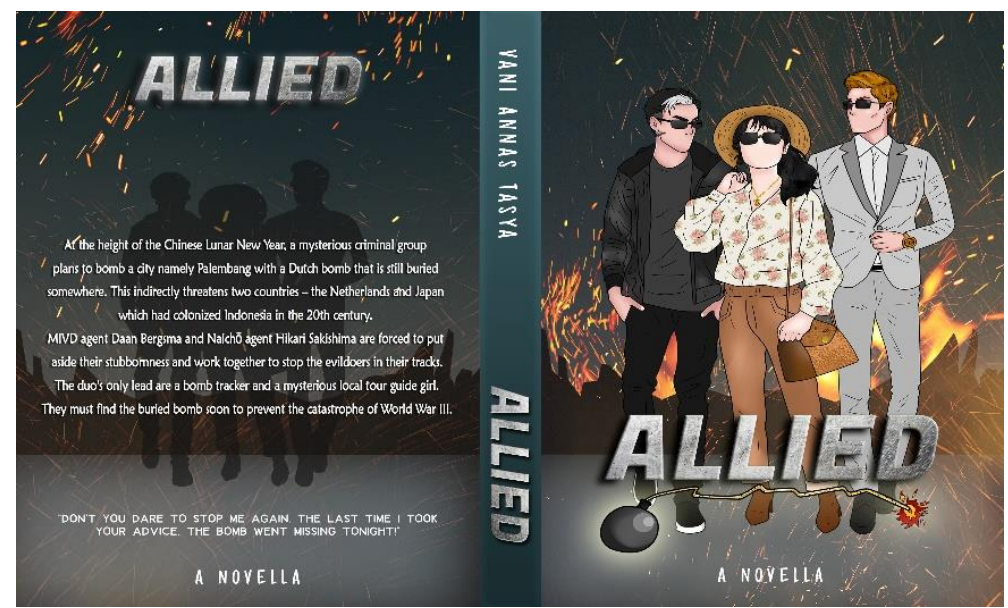

Figure 3.1. A printing cover of Novella

\subsubsection{Dissemination}

After the final product finished, the writer published the product through a Wattpad application. This is done so that the story of the novella can be read by many readers in the world. Moreover, the story is on first ranks on Palembang hashtag among 2.300 stories on Wattpad. The username of the account Wattpad is @Vaniannas. In addition, it can also be accessed by tapping this link https://www.wattpad.com/user/vaniannas.

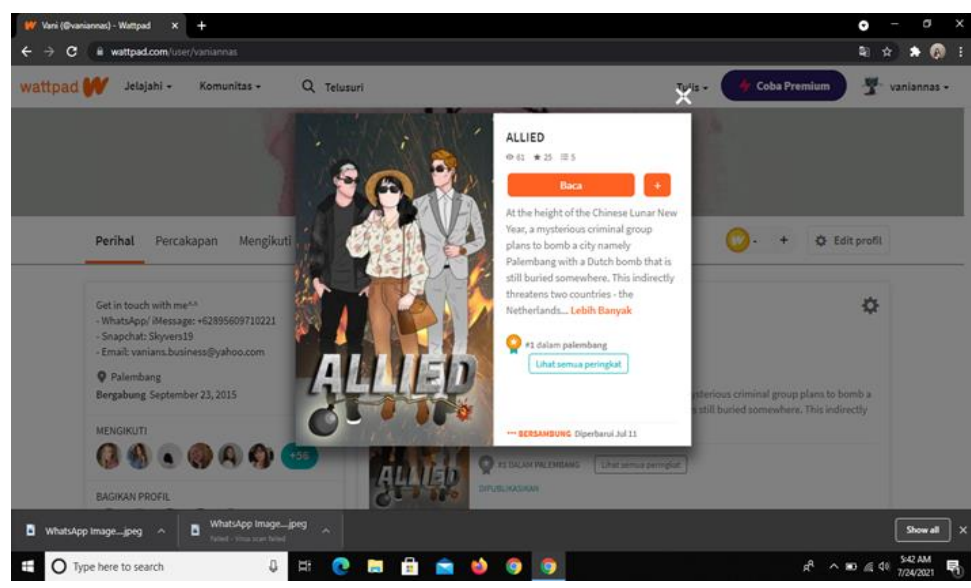

Figure 3.2. Novella is uploaded on Wattpad

\section{CONCLUSION}

In writing a novella entitled "Allied", the writer concluded that there were three steps. The writer used Research and Methodology method [8] which was linked to the steps of writing a story [5]. First in 
Preliminary Study, the writer did the steps starting from getting ideas, choosing ideas, outlining, and drafting. Second in Model Development which consists of limited testing and wider testing, the writer did the step of revising based on the suggestion and comments from several experts. Third, in Final Product, the writer did the last step that was editing based on the feedbacks in revision step. Finally, the novella draft was printed out into a book as a final product and for the dissemination it was uploaded to Wattpad so that it can be read by many readers in the world.

Based on the process that has been done, this novella can be used to promote some tourism destinations in Palembang. Moreover, the novella was written in English which wrapped in action genre that would entertain and educate the readers at the same time.

\section{ACKNOWLEDGEMENTS} research

Authors would like to express deeply gratitude to the experts and participants involved during the

\section{REFERENCES}

[1] B. R. Pope, "Creative Writing: How to Get Started with Creative Writing [+ 9 Exercises]," Self Publishing School, https://self-publishing-school.com/creative- writing/\#topics (Accessed May. 1, 2021).

[2] Choeda, The Origin an Development of English Novel: A Descriptive Literature Review, Bhutan: Samtse College of Education, 2019.

[3] H. M. Harcourt, Journeys: Common Core Writing Handbook Teacher's Guide Grade 4, Portland: Irish Booksellers, 2012.

[4] International Association of Professional Writers \& Editors, "World Count Separates Short Stories from Novelettes and Novellas," Iapwe.org, https://iapwe.org/word-count-separates-short-stories-fromnovelettes-and-\%20novellas/ (Accessed May. 1, 2021).

[5] K. Grenville, Writing from Start to Finish A Six-Step Guide, Crows Nest: Allen and Unwin, 2001.

[6] Master Class (Eds), "How to Write A Novella: Step-By-Step Guide," Master Class, https://www.masterclass.com/articles/how-to-write-a-novella\#3-different- types-of-novellas (Accessed Apr. 1, 2021).

[7] M. H. Abrams and G. G. Harpham, A Glossary of Literary Terms, Boston: Wadsworth Cengage Learning, 2009.

[8] N. S. Sukmadinata, Metode Penelitian Pendidikan, Bandung: Remaja Rosdakarya, 2015.

[9] "Novella," in New World Encyclopedia, New York: New World Encyclopedia, 2007 [Online] Available https://www.newworldencyclopedia.org/entry/ Novella (Accessed Apr. 1, 2021).

[10] Portal Informasi Indonesia, "Laskar Pelangi dan Kebangkitan Destinasi Wisata Kelas Dunia," Indonesia.go.id, https://www.indonesia.go.id/ragam/pariwisata/\%20-\%20pariwisata/laskar-pelangi-dankebangkitan-destinasi-wisata-kelas-dunia (Apr. 5, 2021).

[11] R. Ayala, Love Stories: Writing A Romance Novella in Thirty Days or Les, Delhi: Amiga Press, 2015. Accessed on Sept. 15, 2021. [Online]. Available https://books.google.co.id/books? $\mathrm{Id}=\mathrm{mV0rCwAAQBAJ} \& \mathrm{pg}=\mathrm{PT} 22 \& \mathrm{dq}=$ novella+guideliness\&hl.

[12] Y. Smith, "Literary Tourism as A Developing Genre: South Africa's Potential," M.S. Thesis, Dept. Historical and Heritage, University of Pretoria, Pretoria, South Africa, 2012. [Online] Available https://repository.up.ac.za/handle/2263/29043 


\section{BIOGRAPHIES OF AUTHORS}
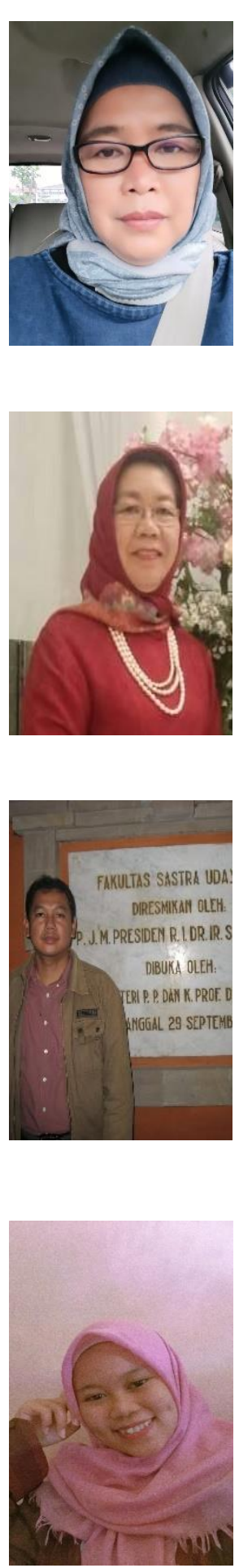

Dr. Nurul Aryanti, M.Pd, was born in Palembang on February, $18^{\text {th }}$ 1968. She completed a bachelor's degree in English Education from University of Sriwijaya in 1992. She continued pursuing postgraduate in 2008 and graduated in 2010 with a master's degree in English Education from University of Sriwijaya. She graduated with Doctoral Degree in Literature Education 2017 from University of Negeri Jakarta, Indonesia. The study programs taught include are Academic Writing, Communication for Business, and Business Correspondence.

Dra. Murwani Ujihanti, M.Pd, was born in Semarang on February, $17^{\text {th }} 1959$. She completed her bachelor's degree of English Literature in Diponegoro University in 1984. She continued pursuing postgraduate in 2001 and graduated in 2003 with a master's degree in English Education from University of Sriwijaya. The study programs taught include are Reading Comprehension, Academic Writing, and Business Correspondence.

Dr. Welly Ardiansyah, S.S, M.Pd, was born in Palembang on August, $17^{\text {th }} 1974$. He completed his bachelor's degree in English Literature from STBA Methodist. He continued pursuing postgraduate in 2002 and graduated in 2005 with a master's degree in English Education from University of Sriwijaya. He graduated with a Doctor's Degree in Curriculum Development from University of Pendidikan Indonesia. The study programs taught include are Reading Comprehension, Research Methodology, Academic Writing, and Business Correspondence.

Vani Annas Tasya, A.Md. Li, was born in Palembang on September 19 $9^{\text {th }}$ 2000. She earned an associate degree in English Department from State Polytechnic of Sriwijaya in 2021. 


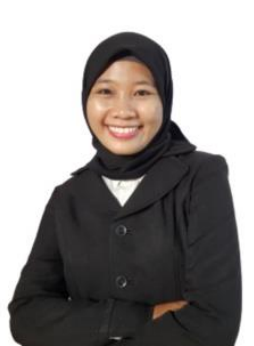

Vasa Annisa Indina, A.Md. Li, was born in Palembang on September $3^{\text {rd }}$, 2000. She earned an associate degree in English Department from State Polytechnic of Sriwijaya in 2021 . 